\title{
KORELASI KETERAMPILAN MEMBACA PEMAHAMAN TEKS BERITA DENGAN KETERAMPILAN MENULIS TEKS BERITA SISWA KELAS VII SMP NEGERI 17 PADANG
}

\section{Correlation of Reading Text Comprehension Skills with News Text Writing Skills Class Vii Students of Smp Negeri 17 Padang}

\author{
Insyani Mai Tari* \& Afnita \\ Pendidikan Bahasa Indonesia, Fakultas Bahasa dan Seni, Universitas Negeri Padang \\ Pos-el: insyanimaitari00@gmail.com
}

\begin{abstract}
Abstrak
Terdapat tiga tujuan dalam penelitian ini sebagai berikut. Pertama, penelitian ini mendeskripsikan keterampilan membaca pemahaman teks berita siswa kelas VIII SMP Negeri 17 Padang. Kedua, penelitian ini mendeskripsikan keterampilan menulis teks berita siswa kelas VIII SMP Negeri 17 Padang. Ketiga, penelitian ini untuk menganalisis korelasi antara keterampilan membaca pemahaman teks berita dengan keterampilan menulis teks berita siswa kelas VIII SMP Negeri 17 Padang. Jenis penelitian ini ialah penelitian kuantitatif deskriptif. Desain penelitian yang diterapkan dalam penelitian ini ialah hubungan korelasional dari dua variabel. Populasi dalam penelitian ini ialah siswa kelas VIII SMP Negeri 17 Padang tahun ajaran 2019/2020.Sampel dalam penelitian ini berjumlah 32 orang siswa. Sampel diambil menggunakan teknik acak sederhana atau simple random sampling. Instrumen penelitian ini ialah tes objektif dan tes unjuk kerja. Berdasarkan analisis data diperoleh tiga hasil dari penelitian ini. Pertama, keterampilan membaca pemahaman siswa kelas VIII SMP Negeri 17 Padang dengan kualifikasi baik dengan nilai ratarata 81,80. Kedua, keterampilan menulis teks berita siswa kelas VIII SMP Negeri 17 Padang dengan kualifikasi baik dengan nilai rata-rata 72,30. Ketiga, terdapat hubungan yang signifikan antara hubungan keterampilan membaca pemahaman teks berita dengan keterampilan menulis teks berita siswa kelas VIII SMP Negeri 17 Padang memiliki hubungan pada level signifikan 95\%. Berdasarkan pada uji hipotesis diterima keterampilan menulis teks berita berada juga pada kualifikasi cukup (76-85\%). Berdasarkan hasil penelitian tersebut, $\mathrm{H}_{0}$ ditolak dan $\mathrm{H}_{1}$ diterima karena hasil pengujian membuktikan bahwa t hitung lebih besar dari t tabel yaitu 8,01>1,63.
\end{abstract}

Kata Kunci : Korelasi, Keterampilan Membaca Pemahaman, Keterampilan Menulis Teks Berita.

\begin{abstract}
There are three objectives in this study as follows. First, this study describes the reading comprehension skills of the eighth grade students of SMP Negeri 17 Padang. Second, this study describes the writing skills of the eighth grade students of SMP Negeri 17 Padang. Third, this study was to analyze the correlation between reading comprehension skills of the news text and writing skills of the eighth grade students of SMP Negeri 17 Padang. This type of research is descriptive quantitative research. The research design applied in this study is a correlational relationship of two variables. The population in this study were students of class VIII SMP Negeri 17 Padang in the academic year 2019/2020. The samples in this study were 32 students. Samples were taken using simple random sampling or simple random sampling. The research instruments are objective tests and performance tests. Based on data analysis, three results were obtained from this study. First, reading comprehension skills of class VIII students of SMP Negeri 17 Padang with good
\end{abstract}


qualifications with an average score of 81.80. Second, the skills of writing news texts for eighth grade students of SMP Negeri 17 Padang with good qualifications with an average score of 72.30 . Third, there is a significant relationship between the relationship between reading comprehension skills and news text writing skills of eighth grade students of SMP Negeri 17 Padang which has a significant level of $95 \%$. Based on the hypothesis test, it is accepted that the skills in writing news texts are also in sufficient qualifications (76-85\%). Based on the results of the study, $H_{0}$ is rejected and $H_{1}$ is accepted because the test results prove that $t$ count is greater than $t$ table, namely 8.01> 1.63 .

Keywords: Correlation, Reading Comprehension Skills, News Text Writing Skills.

\section{PENDAHULUAN}

Pembelajaran Bahasa Indonesia dalam kurikulum 2013 secara umum bertujuan agar peserta didik memiliki keterampilan menyimak, membaca, berbicara, menulis, menyaji, dan memirsa. Pada kurikulum 2013 pembelajaran Bahasa Indonesia dipusatkan pada pembelajaran berbasis teks. Pembelajaran berbasis teks lebih memusatkan pada siswa untuk memahami dan memproduksi teks baik dalam bentuk lisan maupun tulisan. Aspek berbahasa terdiri dari dua keterampilan yakni keterampilan memahami dan keterampilan memproduksi. Suyono (2018:204) menyatakan bahwa keterampilan memahami, berpikir, menulis merupakan inti kegiatan yang sangat diperlukan siswa untuk menyelesaikan studi dan melanjutkan studi oleh karena itu, siswa dituntut untuk bisa memproduksi sebuah teks dengan baik.

Keterampilan menulis salah satu aspek keterampilan berbahasa yang harus dikuasai oleh siswa, dengan keterampilan menulis yang memadai siswa mampu menuangkan ide, gagasan, pikiran, perasaan, dan pengetahuan dalam bentuk tulisan yang diwujudkan dalam bentuk teks. Keterampilan menulis merupakan suatu keterampilan dasar yang menunjang keberhasilan pembelajaran semua mata pelajaran di sekolah.

Salah satu keterampilan menulis yang dimuat dalam Kurikulum 2013 di tingkat Sekolah Menengah Pertama (SMP) kelas VIII semester 1 mata pelajaran Bahasa Indonesia ialah menulis teks berita. Terdapat pada Kompetensi Inti (KI) 4 yakni "Mencoba, mengolah, dan menyaji dalam ranah konkret (menggunakan, mengurai, merangkai, dan mengarang) dan ranah abstrak (menulis, membaca, menghitung, menggambar, dan mengarang). Kompetensi Dasar dari keterampilan menulis teks berita (KD) 4.2 yakni "menyajikan data, informasi dalam bentuk berita secara lisan dan tulisan dengan memperhatikan struktur, kebahasaan, atau aspek lisan (lafal, intonasi, mimik, kinestik).

Keterampilan menulis merupakan pengungkapan pendapat terhadap sesuatu menggunakan media tulisan (Aidawati, 2016). Selain itu, Thahar (2008:2) menyatakan bahwa kegiatan menulis merupakan kegiatan intelektual 
yang menandai seseorang intelektual dengan kemampuannya mengekspresikan jalan pikirannya melalui tulisan dengan media bahasa. Selanjutnya, Gani (2011:1) mengemukakan bahwa keterampilan menulis merupakan proses melambangkan bunyi-bunyi ujaran berdasarkan aturan tertentyu. Jadi, keterampilan menulis ialah keterampilan mengemukakan ide, gagasan, atau pikiran dalam bentuk tulisan.

Ermanto (2016) menyatakan bahwa keterampilan menulis teks berita merupakan salah satu aspek keterampilan menulis, menulis teks berita merupakan teks yang menyampaikan fakta atau peristiwa di kehidupan melalui tulisan, alat penyampaiannya ialah bahasa dalam bentuk kata, frasa, klausa, kalimat, paragraf, dan wacana. Jadi, keterampilan menulis teks berita ialah keterampilan menuangkan ide, gagasan, informasi, fakta, serta peristiwa di kehidupan melalui bahasa dan bentuk kata, frasa, klausa, kalimat, paragraf, dan wacana/

Keterampilan membaca pemahaman merupakan salah satu keterampilan yang sangat penting dikuasai oleh siswa sebagaimana diungkapkan Inderjit (2014) menyatakan bahwa keterampilan membaca pemahaman penting dikuasai oleh siswa karena meningkatkan pemahaman membaca, gaya bahasa, kosakata, dan pengembangan tata bahasa. Agustina (2008:15) yang menyatakan bahwa tujuan membaca pemahaman ialah untuk menangkap isi atau makna dari gagasan-gagasan yang terdapat dalam bacaan. Hal ini termasuk dalam membaca lebih mengutamakan makna bacaan pada setiap tulisan.
Berdasarkan wawancara yang dilakukan dengan guru Bahasa Indonesia Kelas VIII SMP Negeri 17 Padang yakni ibuk Atriyanti, S.Pd. ditemukan beberapa permasalahan terkait dengan keterampilan menulis teks berita siswa. Permasalahan yang diperoleh sebagai berikut. Pertama, masih kurangnya keterampilan membaca pemahaman siswa mengakibatkan terkendalanya menuangkan ide atau gagasan dalam bentuk tulisan yang dituangkan dalam teks berita. Kedua, siswa mengalami permasalahan dalam mengembangkan unsurunsur berita dan struktur sebuah teks berita. Ketiga, siswa belum dapat menggunakan unsur $5 \mathrm{~W}+1 \mathrm{H}$ secara baik dan keseluruhan. Karena hal ini, peneliti tertarik untuk menganalisis korelasi keterampilan membaca pemahaman teks berita dengan keterampilan menulis teks berita.

Permasalahan yang dihadapi siswa tersebut berpengaruh terhadap pembelajaran menulis teks berita menjadi tidak efektif. Langkah yang dilaksanakan dalam menulis teks berita ialah dengan memahami teks berita. Hubungan keterampilan memahami suatu bacaan dengan keterampilan menulis suatu teks sangat erat. Oleh karena itu, kedua keterampilan tersebut harus dilatihkan agar ditemukan hubungan yang signifikan. Selain itu, memahami dan menulis memiliki nilai penting bagi siswa dalam pembelajaran Bahasa Indonesia di sekolah.

Terdapat beberapa penelitian relevan dengan penelitian ini yaitu, Puspita Dewi (2019), Samirudin (2016), Bimma Geo Fano (2019), 
Taufik Ramadhan (2019), dan Yuni Wirda (2017) kelima penelitian relevan ini mengemukakan bahwa hubungan keterampilan membaca pemahaman teks berita dengan keterampilan menulis teks berita belum membentuk hubungan yang efektif.

Berdasarkan permasalahan tersebut penelitian terhadap hubungan keterampilan membaca pemahaman teks berita dengan keterampilan menulis teks berita penting untuk dilakukan. Oleh sebab itu, peneliti tertarik melakukan penelitian dengan judul "Korelasi Keterampilan Membaca Pemahaman Teks Berita Dengan Keterampilan Menulis Teks Berita Siswa Kelas VIII SMP Negeri 17 Padang".

\section{METODE PENELITIAN}

Penelitian ini termasuk jenis penelitian kuantitatif. Penelitian ini termasuk jenis penelitian kuantitatif karena data yang diolah berupa angka yang diperoleh dari hasil tes keterampilan membaca pemahaman teks berita dengan keterampilan menulis teks berita. Metode yang diterapkan dalam penelitian ini adalah metode deskriptif. Peneliti memilih untuk menerapkan metode ini karena tujuan dari peneliti ialah untuk mendeskripsikan, mencatat, menganalisis, dan menginterprestasikan keadaan-keadaan yang terjadi saat itu. Rancangan penelitian ini ialah korelasional. Rancangan penelitian ini diterapkan untuk menganalisis hubungan korelatif antara dua variabel, yakni menganalisis korelasi keterampilan membaca pemahaman teks berita dengan keterampilan menulis teks berita siswa kelas VIII SMP Negeri 17 Padang.

Populasi dalam penelitian ini adalah seluruh siswa kelas VIII SMP Negeri 17 Padang tahun ajaran 2019/2020. jumlah siswa kelas VIII SMP Negeri 17 Padang yang terdaftar ialah 198 siswa yang tersebar dalam tujuh kelas. Teknik pengambilan sampel yang diterapkan dalam penelitian ialah teknik secara acak sederhana atau simple random sampling, yakni penarikan sampel berdasarkan proposi jumlah siswa per kelas. Penelitian ini memiliki dua variabel, yakni varibel bebas $(\mathrm{X})$ dan variabel terikat $(\mathrm{Y})$. Variabel bebas (X) dalam penelitian ini ialah keterampilan membaca pemahaman teks berita siswa dan variabel terikat (Y) dalam penelitian ini ialah keterampilan menulis teks berita siswa kelas VIII SMP Negeri 17 Padang. Data dalam penelitian ini ialah skor tes objektif terkait dengan keterampilan membaca pemahaman teks berita dan skor tes unjuk kerja terkait keterampilan menulis teks berita.

Instrumen penelitian merupakan suatu alat yang digunakan untuk mengukur kemampuan siswa. Instrumen yang digunakan dalam penelitian ini ialah tes. Tes diterapkan untuk mengukur keterampilan membaca pemahaman teks berita dan tingkat keterampilan menulis teks berita siswa kelas VIII SMP Negeri 17 Padang, bentuk tes yang diterapkan dalam penelitian ini ialah tes objektif dan tes unjuk kerja.

\section{PEMBAHASAN}


Dalam penelitian ini pembahasan yang dijelaskan sebagai berikut, (1) keterampilan membaca pemahaman teks berita siswa kelas VIII SMP Negeri 17 Padang (2) keterampilan menulis teks siswa kelas VIII SMP Negeri 17 Padang, dan (3) korelasi keterampilan membaca pemahaman teks berita dan keterampilan menulis teks berita siswa kelas VIII SMP Negeri 17 Padang.

\section{Keterampilan Membaca Pemahaman Teks Berita Siswa Kelas VIII SMP Negeri 17 Padang}

Berdasarkan hasil dari penelitian dan hasil analisis data, dapat diketahui bahwa keterampilan membaca pemahaman teks berita siswa kelas VIII SMP Negeri 17 Padang diklasifikasikan menjadi tiga kategori yakni Baik, lebih dari cukup, dan cukup. Nilai rata-rata keterampilan membaca pemahaman teks berita siswa kelas VIII SMP Negeri 17 Padang berada 81,80 dengan tingkat pengguasaan (76-85\%) berada pada kualifikasi baik pada skala 10 .

Indikator yang paling dikuasai siswa ialah indikator memahami struktur teks berita dengan nilai rata-rata 83,16 dengan tingkat penguasaan (76-85\%) berada pada kualifikasi baik pada skala 10 . berdasarkan nilai rata-rata dapat diketahui sebagian besar siswa sudah mulai memahami struktur teks berita hal ini dapat dilihat dari nilai yang diperoleh siswa berada pada kualufikasi baik.

Indikator yang kurang dikuasai oleh siswa adalah indikator unsur 5W 1W teks berita.
Nilai rata-rata siswa 73,45 dengan tingkat penguasaan (66-75\%) berada pada kualifikasi cukup pada skala 10 . berdasarkan nilai rata-rata tersebut dapat diketahui bahwa siswa masih mengalami kesulitan untuk menguasai unsur 5W 1H yang terdapat dalam sebuah teks berita.

Berdasarkan pembahasan tersebut, dapat disimpulkan bahwa nilai keterampilan membaca pemahaman teks berita siswa kelas VIII SMP Negeri 17 Padang masih berada di kualifikasi baik. Oleh karena itu keterampilan membaca pemahaman teks berita siswa kelas VIII SMP Negeri 17 Padang perlu ditingkatkan lagi. Hal ini sejalan dengan pelaksanaan tes objektif yang diterapkan untuk mengukur keterampilan membaca pemahaman siswa kelas VIII SMP Negeri 17 Padang sudah melibatkan proses berpikir dalam menganalisis setiap butir soal yang diberikan.

\section{Keterampilan Menulis Teks Berita Siswa Kelas VIII SMP Negeri 17 Padang}

Keterampilan menulis teks berita siswa kelas VIII SMP Negeri 17 Padang berdasarkan rata-rata hitung 72,30 diklasifikasikan menjadi kategori baik. Karena berada dalam rentang (76$85 \%$ ) pada skala 10. hal ini disebabkan siswa masih kurang mampu untuk menuangkan ide, pikiran, gagasan, dan perasaan dalam bentuk tulisan. Kurangnya kemampuan siswa ini terlihat dari rata-rata hitung indikator bahasa teks berita sebesar 53,25.

Selanjutnya, analisis data keterampilan menulis teks berita siswa kelas VIII SMP Negeri 
17 Padang menunjukkan rata-rata hitung ketiga indikator, unsur-unsur teks $(76,70)$, kualifikasi baik (B), struktur teks $(82,00)$ kualifikasi baik (B), bahasa teks $(72,30)$ kualifikasi cukup (C). dari analisis tersebut, kesalahan paling banyak dilakukan siswa terdapat pada indikator bahasa dengan rata-rata nilai 53,25 dan kesalahan paling sedikit yang dilakukan siswa terdapat pada indikator struktur teks.

Bertolak dari hasil penilaian tulisan teks berita siswa, dapat disimpulkan bahwa keterampilan menulis teks berita siswa, khususnya untuk indikator bahasa berita sebagai alat untuk memberikan kepercayaan kepada pembaca bahwa topik yang ditulis ialah topik yang penting untuk dibahas belum tercapai. Ketidaktercapaiannya ini disebabkan karena lemahnya bahasa berita. Selain itu, siswa menyakinkan pembaca juga dipengaruhi oleh pengguasaan afiks, penggunaan pronomina, penggunaan frasa, yang belum sesuai dengan kaidah ejaan bahasa indonesia yang baik dan benar.

\section{Korelasi Keterampilan Membaca Pemahaman Teks Berita Dengan Keterampilan Menulis Teks Berita Siswa Kelas VIII SMP Negeri 17 Padang}

Berdasarkan hasil deskripsi dan analisis data, dapat disimpulkan bahwa terdapat hubungan signifikan antara keterampilan membaca pemahaman teks berita dan keterampilan menulis teks berita siswa kelas
VIII SMP Negeri 17 Padang. Hal ini terbukti dengan hasil penelitian yang menunjukkan bahwa keterampilan membaca pemahaman teks berita dengan keterampilan menulis teks berita siswa kelas VIII SMP Negeri 17 Padang berada pada kualifikasi baik $(81,80)$, keterampilan menulis teks berita berada juga pada kualifikasi cukup (76-85\%). berdasarkan hasil penelitian tersebut, $\mathrm{H}_{0}$ ditolak dan $\mathrm{H}_{1}$, diterima karena hasil pengujian membuktikan bahwa thitung lebih besar dari ttabel yaitu 8,01>1,63.

Bertolak dari hasil temuan tersebut dapat disimpulkan bahwa keterampilan membaca terbukti memberikan sumbangan yang sangat signifikan terhadap keterampilan menulis. Untuk itu, jika ingin meningkatkan keterampilan menulis, terlebih dahulu keterampilan membaca harus ditingkatkan.

\section{SIMPULAN}

Berdasarkan deskripsi data, dapat disimpulkan tiga hal. Pertama, Keterampilan membaca pemahaman teks berita siswa kelas VIII SMP Negeri 17 Padang dengan rata-rata hitung berjumlah 81,80. kedua, keterampilan menulis teks berita siswa kelas VIII SMP Negeri 17 Padang berada pada kualifikasi baik. Hal ini disimpulkan berdasarkan rata-rata hitung yang berjumlah 72,30. ketiga, terdapat hubungan yang signifikan antara keterampilan membaca pemahaman teks berita dengan keterampilan menulis teks berita siswa kelas VIII SMP Negeri 17 Padang berada pada kualifikasi baik, keterampilan menulis teks berita berada pada 
kualifikasi cukup (76-85\%). berdasarkan hasil penelitian tersebut, $\mathrm{H}_{0}$ ditolak dan $\mathrm{H}_{1}$ diterima karena hasil pengujian membuktikan bahwa thitung lebih besar dari ttabel yaitu 8,01>1,63. berdasarkan hasil pengujian tersebut, dapat disimpulkan bahwa siswa memiliki keterampilan menulis teks berita yang baik, juga memperoleh nilai keterampilan menulis teks berita yang tinggi. Sebaliknya, jika siswa memperoleh nilai keterampilan menulis teks berita yang rendah, juga memperoleh nilai keterampilan membaca teks berita yang rendah.

\section{DAFTAR PUSTAKA}

Agustina. (2008). "Pembelajaran Keterampilan Membaca" (buku ajar). Padang: Jurusan Bahasa dan Sastra Indonesia FBS UNP. (diunduh 12 Febuari 2020).

Aidawati, N. (2016). "Meningkatkan Keterampilan Menulis Teks Berita Dengan Menggunakan Model Pelajaran Project Basic Learning (PJBL) pada Siswa Kelas XII di SMK Negeri 1 Samarinda Tahun Pelajaran 2015/2016. Jurnal Ilmu Pendidikan LPMP Kalimantan Timur, Vol. 10, No.2 (online). http://lpdpkalim. kemendikbud.go.id (diunduh tanggal 12 Febuari 2020).

Ermanto. (2016). "Hubungan Keterampilan Membaca Pemahaman Berita dengan Keterampilan Menulis Teks Berita" (artikel jurnal) Padang: Jurnal Bahasa dan Sastra Indonesia. Vol.5. (diunduh 12 Febuari 2020).

Inderjit, S. (2014). Reading Trends And Improving Reading Skills Among Student In English Language. Internasional Journal Of Instruction. Jully 2013, Vol.6, NO 2 p-ISSN : 1694- 6096X (diunduh 12 Febuari 2020).

Gani, E. (2011). Komponen-Komponen Karya Tulis Ilmiah. Bandung: Pustaka Cipta.

Semi, M.A. (2009). Menulis Efektif. Padang: UNP Press.

Thahar, H.E. (2001), Menulis Efektif: Panduan Bagi Pemula. Padang: UNP Press. 